\title{
Revisionist Tendencies in Historical Research into German Fascism
}

\author{
KARL HEINZ ROTH
}

\section{INTRODUCTION: THE EUROPEAN SCENARIO}

Anybody pursuing recent trends in historical studies of fascism is well advised to begin by looking at the present political landscape in Europe. The political and socio-economic upheavals in Eastern and South-Eastern Europe since 1989/1990 have made the increasing time-interval from the fascist phenomenon redundant and also given topicality to historical formulations concerning that huge European area dominated by the Nazi dictatorship in the years 1938 to 1944. Our starting-point is one which was, up to recently, unthinkable: namely that in some countries of Eastern and South-Eastern Europe the new elite groups in power after the collapse of so-called "real socialism" use "ethnic land re-allocation" in their policy of "delayed nation-building" and legitimize their claims with historical examples from the fascist era of the late 1930s and early 1940s. At the same time, intellectual elites striving for power in Western and Southern Europe more or less redefine the various fascisms of the past (Action Française, Italian fascism, Austrofascism, German fascism) as part of their own historical tradition of right-wing populism and justify more and more the collaboration of their populations with the Nazi occupying forces during the war.

An exemplary case of the political significance of historical revisionism in connection with German fascism can be seen in the careers of the government leaders in the former Jugoslav republics. Franjo Tudjman, a former major in the Jugoslav partisan movement, made a successful career as an historian in the $1960 \mathrm{~s}$, when he dealt intensively with the genocidal crimes of the Nazi occupiers on the south-eastern periphery of Europe. ${ }^{1}$ At a conference on the European resistance movement

\footnotetext{
1 Tudjman was bom in 1922 and joined Tito's partisans in 1941. At the end of the war he held the rank of major and was pensioned off in 1961 as major-general. He wrote a $\mathrm{Ph}$.D. on the reasons for the crisis of the Jugoslav monarchy. In 1961-1967 he was Director of the Institute for the History of the Croatian Labour Movement in Zagreb and from 1963 professor at the Institute for Political Science there. He was expelled in 1967 from the Jugoslav CP for his activities in a separatist Croatian organization. He was imprisoned in 1972 and 1981 . When the multi-party system was introduced in February 1990. Tudjman became Chairman of the Croatian Democratic Union. The transformation of his historical thought can be traced in the following publications: Franjo Tudjman, Rat protiv rata (Zagreb, 1957); idem, Okupacija i revolucija (Zagreb, 1963); idem, Nationalism in Contemporary Europe (New York, 1981); idem, Bespuca (Zagreb, 1989); idem, "Croatia at the Crossroads. In Search of a Democratic Confederacy", in Centre for Policy Studies (ed,), Policy Challenge (London, 1991).
}

International Review of Social History 39 (1994), pp. 429-455 
Tudjman, then (1963) Director of the Institute for the History of the Croatian Labour Movement, characterized the rule of terror carried out by the Croatian Ustascha regime as follows:

On the territory of the independent Croatian State Ustaschi and Germans unleashed a reign of terror and murder which was specifically aimed at Communists, other anti-fascists, Serbs and Jews [. . . The goal of the Ustascha persecution of Jews and Serbs was to "catholicize", deport or liquidate them. This policy was executed by means of forced naturalisation, forced conversion and the compulsory registration of Jewish property.?

Twenty-six years later Tudjman, now a ultranationalistic separatist, legitimized these very events in a well-publicized book. He wrote that the building of "Hitler's New European Order" was justified on the grounds of mutual need on the part of occupiers and collaborators alike; so too was

the removal of the Jews (more or less unwanted in all European countries) as well as the correction of that Anglo-French transgression - the Versailles Treaty [...] In the mid-80s, World Jewry thought fit to remind us of its "Holocaust" and even went so far as to attempt to prevent Karl Waldheim, the former General Secretary of the UNO, from being elected President of Austria. ${ }^{3}$

Since then Tudjman has got himself elected President of Croatia. No other historian has attained such heights, although in a time-span of 2025 years quite a few historians have completed a full about-turn in their evaluation of the fascist past in their own countries and in Europe generally. Since the end of the 1970 s they have provided an essential intellectual contribution to Jugoslav irredentism. In the Baltic States and the Ukraine former collaborators of the German occupation and liquidation administrations have been rehabilitated, due to the propaganda of the collaborators themselves. This was initiated in the early 1980 s in exile and also found support in the writings of internationally-known historians. ${ }^{4}$ In the German Federal Republic, Ernst

${ }^{2}$ Franjo Tudjman, "The Independent State of Croatia as an Instrument of the Policy of the Occupation Powers in Yugoslavia and the People's Liberation Movement in Croatia from 1941 to 1945", in Les sy'stmes d'occupation en Yugoslavie 1941-1945. Rapports au 3e Congres International sur l'histoire de la Résistance eturoptene Karlovy Vary (Belgrade, 1963), p. 192.

Tudjman, Bespuca, quoted from Karl Pfeifer, "Der Prásident und die Juden. Auch Franjo Tudjman ist ein zeitgemaßer Mann", Fonum, 456, 18 December 1991, pp. 11-15, here p. 12.

- For example, the Ukrainian historian Taras Hunezak, history lecturer at Rutgers University, who, from the 1980s onwards, played down the Ukrainian collaboration with the Nazis and how they cooperated in the mass exterminations: see Taras Hunczak, "Ukrainian-Jewish Relations during the Soviet and Nazi Occupations", in Yury Boshyk (ed.). Ukraine during World IVar II. History and Its Aftermath (Edmonton, 1986), pp. 39-57; idem. "The Ukrainian Losses during World War II", in Michael Berenbaum (ed.), A Mosaic of Victims. Non Jew's Persecuted and Mfurdered by the Nazis (London and New York, 1990), pp. 116-127. 
Nolte, ${ }^{5}$ an analyst of comparative fascisms who felt humiliated by leftwing students in the early 1970s, stated that German fascism could reasonably be legitimized as a defensive reaction of the European middle classes to the "Bolshevik threat" of 1917-1918. In the course of the historians' dispute ("Historikerstreit") he had thus provoked, Nolte's views became progressively more radical. ${ }^{6}$ Parallel to the repopularization of Vichy slogans, the French "Cercles Pétain" gained increasing acceptance, and the French Resistance has lately been described as the work of a handful of top Soviet agents. ${ }^{7}$ In the 1980s Italian fascism, too, enjoyed political acceptance once more, on the basis of references to its technocratic, state-building structures. ${ }^{8}$ Early last year the British history lecturer John Charmley accused Churchill of having squandered the British Empire and thereby provoking the social reforms of the Labour Party after 1945 because he had rejected the idea of a separate peace treaty with Hitler in the years 1940/1941. ${ }^{9}$

${ }^{3}$ Ernst Nolte was born in 1923 in Witten in the Ruhr region. He studied philosophy and philology and received his Ph.D. in 1952 for a thesis on "Selbstentfremdung und Dialektik im deutschen Idealismus und bei Karl Marx". Afterwards he was a secondary school teacher for 13 years. In 1963 he published a comparative study about "fascism in its epoch" and was appointed one year later to the Chair of Modern History at the University of Marburg. There he had traumatic clashes with the followers of Wolfgang Abendroth's neo-Marxist fascism theory. Nolte co-founded an association for "freedom in science" and went over to the Right. In 1973 he was given the professorship for Modern History in Berlin (Freie Universitat), where he taught until his retirement in 1989. The theses with which Nolte started the Historikerstreit in 1986 could be read in his publications since the beginning of the 1970s.

- Ernst Nolte, "Vergangenheit, die nicht vergehen will. Eine Rede, die geschrieben, aber nicht gehalten werden konnte", Frankfurter Allgemeine Zeinung, 6 June 1986, reprinted in Historikerstreit. Die Dokumentation der Kontroverse um die Einzigartigkeis der national. sozialistischen Judenverfolgung (Munich and Zurich, 1987), pp. 39-47; idem, Das Vergehen der Vergangenheit. Annwort an meine Kritiker im sogenannten Historikerstreit (Berlin and Frankfurn, 1987); idem, Der europaische Burgerkrieg 1917-1945. Nationalsozialismus und Bolschewismus (Frankfurt and Berlin, 1987); idem, "AbschlieBende Reflexionen aber den sogenannten Historikerstreit". in Uwe Backes, Eckhard Jesse and Rainer Zitelmann (eds), Die Schatuen der Vergangenheit. Impulse zur Historiziernung des Nationalsozialismus (Frankfurt and Berlin, 1990), pp. 83-109; idem, Streitpunkte. Heutige und kilnfrige Kontro. versen um den Nationalsozialismus (Frankfurt and Betlin, 1993). For his critics see especially: Hans Mommsen, "Das Ressentiment als Wissenschaft. Anmerkungen zu Emst Noltes Der europdische Burgerkrieg 1917-1945. Nationalsosialismus und Bolschewismus", Geschichte und Gesellschaft, 14 (1988), pp. 495-512.

Thierry Wolton, Le Grand Recrutement (Paris, 1993). For a critique of revisionism in France see especially: Pierre Vidal-Naquet, Les assassins de la mémoire (Paris, 1987); Thierry Maricourt, Les nouvelles passarelles de l'extrême droite (Levallois-Perret, 1993); Pierre Vidal-Naquet, Le srait empoissonne. Réflexions sur l'affaire Jean Moutlin (Paris, 1993).

'See Tim Mason, "Il fascismo 'Made in Italy". Mostra sull'economia italiana tra le due guerre", ltalia comremporanea, 158 (1985), pp. 5-32; idem, "Moderno, modernita, modernizzazionc: un montaggio", Movimento operaio e socialista, new series 10 (1987), Pp. 45-61.

'John Charmley, Churchill: The End of Glony. A Political Biography' (London, 1993). 
Alongside these right-wing, populistic and revisionist tendencies we can observe for some time within the irredentist groupings of European neo-fascism publicists who employ historical arguments - renegades, young careerists, irredeemable Nazis. ${ }^{10}$ In so far as they were collaborators in the years of the "real socialist" regimes, they have since returned to their countries of origin or - in the case of Germany and Austria fought their way in the last few years to the forefront of "respectable" journalism. The most important German equivalent of a group pledged to rehabilitate the collaborators of European fascism can be found among former junior officers who served in German military counter-intelligence or the Waffen-SS. They propagate the Nazi doctrine of a "Europe of the Peoples" - under German domination, of course - as an excellent model for future development. In this respect the ideas emanating from the Central Office of the SS (SS-Hauptamt) in the years 1943-1944 have gained a certain notoriety and are presented as an alternative to Maastricht: "European passports", "Federal Plans" (Hans Werner Neulen)."

\section{FROM REVISIONIST HISTORICAL PROPAGANDA TO THE SYSTEMATICS OF SCIENTIFICALLY-BASED REHABILITATION}

Since the "Historikerstreit" we can see from the work of Neulen or Nolte that revisionist historical propaganda is steadily gaining ground in Germany. Nolte, for example, justified fascist mass-extermination policies as being reactive, anti-Bolshevik tactical moves in the "logical" strategy of a "European Civil War". ${ }^{12}$ While the affirmative framework of such propaganda can hardly be overlooked, there are considerable differences of opinion regarding the preference for one form of fascist domination over another in presenting solutions for the present "system crisis". All such currents have the following in common: a strong tendency to racialist escalation, to projecting social conflicts inwards ("ethnicization of social questions"); laying claims to participation in undemocratic rule by "experts"; revising the present German borders within a "federal" Europe," based on a strictly hierarchical system run

to They find a German-speaking forum in the magazines: Criticon, MUT, Junge Freiheit, Nation Europa.

"See especially Hans Werner Neulen, Eurofaschismus und der Zweire Weltkrieg. Europas verratene Sohne (Munich, 1980); idem, Europa und das 3. Reich. Einigungsbestrebungen im deutschen Machtbereich 1939-45 (Munich, 1987); idem, An deutscher Seite. Internationale Freiwillige von Wehmaciut und Waffen-SS (2nd ed., Mfunich, 1992). These books are based on documents in the private archives of former Nazi Party and SS functionaries. especially that of the former planning expert in SS-Central Office. Alexander Dolezalek, in Votho an der Weser.

12 This concept is not Nolte's, as is generally believed, but was coined by SS-intellectuals in 19+4-1945 in order 10 justify the planning of an underground war behind the Allied lines.

13 In addition, the West Berlin historian Armulf Baring calls for military intervention in the case of unrest in "the vacuum East Europe" and sealing off the eastern border to 
according to socio-economic "performance" results. It is not particularly difficult to argue theoretically against such a model, as the historical tradition of the period of Nazi occupation and collaboration - the legitimation of the Right - provides, on a closer analysis of the war period, an unequivocally negative picture of fascist-dominated Europe. This negative verdict is bound to be underlined further by the examination of empirical sources, for example the planning and actually implementing the mass extermination of whole population groups; enforcing conditions of indentured or slave labour within the Nazi system.

However, it is not quite so easy to refute the claims of a young group of German historians and political scientists in Berlin, Bielefeld, Bonn and Munich. They invest German fascism with positive attributes, i.e. they see it as a "revolutionary social" variant of a "secular modernization process", ${ }^{14}$ link its "national community" (Volksgemeinschaft) with the contemporary tendency of inverting historical class analysis and exploit for their own ends those interpretations of fascist genocide which ignore the socio-economic conditions prevailing at the time. The main problem is that such well-thought-out opinion can attach itself to the theoretical body of work written by established German historians, thereby simplifying complicated conventional theories and transforming them subtly into a "progressive" and exemplary framework in order to manipulate the historical truth about many areas of Nazi domination. To illustrate this, I will begin by sketching the "modernization theories" of the 1960s and 1970s and then examine how young historians misappropriated and instrumentalized these theories. Then follows a discussion on the ideology behind the concept "Volksgemeinschaft", and also on the transformation of Nazi genocide by means of a "negative" reflection of the modernization theory. Last but not least, we shall turn to the question of how such efforts are shamelessly synthesized in public debate in an effort to propagate an expansionist, exclusively "Grossdeutsch" view of history.

\section{THE MODERNIZATION THEORY IN THE 1960s AND 1970s}

For a considerable time large sections of Anglo-American and German research into the history of the Nazi era has been influenced by the "modernization" paradigm, that is to say, that the years between 1933 and 1945 were marked by a strong surge of modernizing influences in economic, political and cultural fields. The theory that the Nazi dictatorship gave German society a "revolutionary" shove into the "modern" era by instrumentalizing "modernization" tacties in order to

Stop "flooding by emigrants". See Amulf Baring, Deuschland, was num? Ein Gespräch mit Dirk Rumberg und Wolf Jobst Siedler (Berlin, 1991), pp. 115, 166If.

"For an early contribution to this controversy see Karl Heinz Roth, "Verklarung des Abgrunds. Zur nachträglichen 'Revolutionierung' der NS-Diktatur durch die Gruppe um Rainer Zitelmann", 1999, 7 (1992), no. 1, pp. 7-11. 
introduce "regressive" (i.e. pre-1918) social structures, was formulated systematically for the first time by Ralf Dahrendorf in the mid-1960s. ${ }^{15}$ Dahrendorf's argument was that National Socialism surmounted previous divisions of society in isolated social milieux and integrated them on a national basis, albeit unintentionally and rather as the inevitable consequence of its dictatorial system of rule:

The brutal break with tradition and the thrust from behind into the era of "modernity" [. . .] are integral features of National Socialism. ${ }^{16}$

A year after Dahrendorf's book appeared, David Schoenbaum presented the first social history synthesis of the Nazi period. ${ }^{17} \mathrm{He}$ described national-socialist social policy as an antimodernist utopia covered by an ideological mantle, under which the Nazis, in pursuance of the regime's goals, used industrial measures and mobilized society on an extensive basis. A "social revolution" occurred predominantly in the socio-cultural superstructure and found expression - in a scissors-like movement - in social organizations. It was primarily the Deutsche Arbeitsfront (DAF) which accelerated the process of social mobilization and "compensated" the workers for the loss of their trade union rights by affording them more social equality. In the early 1970 s Henry A. Turner rounded off the "antimodern" postulate in the writings on the social and economic history of Hitler's Germany by depicting the "antimodern" utopia of German fascism as a decisive element in its political practice. ${ }^{18}$ The "antimodern" social stereotype of the "frontier farmer" (half-farmer, half-soldier) needed "Lebensraum" to expand. In a divided world this meant war - a war which could be fought only with the means supplied by a highly developed industrial society: "The National Socialists inevitably had to modernise in order to pursue their anti-progressive goals."19 By so drawing on the expansionistic programme of German fascism, Turner made the "ends and means" dichotomy of the German "double revolution" - which Dahrendorf had not reconciled with one another and Schoenbaum left underexposed - convincingly compatible. Various "modernization" models could now be presented as harmonious, watertight, explanatory prototypes for all kinds of microstudies and soon became uncontested among the teachers and students of modern history in West Germany.

On reflection, this development must seem all the more surprising, considering that it represented a methodological regression in modern

is Ralf Dahrendorf, Gesellschaft und Demokratie in Deutschland (Munich, 1965), esp. pp. 431ff.

16 Ibid., p. 432.

17 David Schoenbaum, Hitler's Social Revolution - Class and Status in Nazi Germany 1933-1939 (London, 1966). The German edition: Die braune Revolution - Eine Sozialgeschichte des Dritten Reiches (Cologne, 1968).

"Henry A. Tumer, Faschismus und Kapitalismus in Deutschland (Göttingen, 1972).

19 Henry A. Turner. "Faschismus und Anti-Modernismus", in ibid., p. 172. 
history studies and coincided with a period of intense reflection on the role of the "modernization" concept within the interdisciplinary realms of social history. In this connection I wish to refer to the work of Jürgen Kocka and Hans-Ulrich Wehler since the $1970 \mathrm{~s}^{20}$ Both endeavoured to purify the normative construction of the Anglo-Saxon parliamentary model of capitalism - taken from US development sociology - as a standard and the final goal of history. ${ }^{21}$ It was placed in a somewhat social-liberal variation which took cognizance of social conflicts, argued in favour of breaking the "spell of myths" on the way to the capitalistic "Moderne",22 and proclaimed "the democratic social state for the masses" as a model (Wehler). ${ }^{23}$ The framework of this argument became even more flexible and its immanently strict determinism was moderated by the adoption of the theories of Reinhard Bendix, Alexander Gerschenkorn and Barrington Moore. The latter had formulated various development models stemming from the Anglo-French "double revolution" and linked these with property rights in land and "latecomer" types of societies. To indicate the historical possibilities of contributing to the "well-being of the Republic" on a continuous basis was considered necessary without, however, having to refer to "any single social group" as the moving force. ${ }^{24}$ What Kocka and Wehler concocted was neither a functioning legitimation-model for the ruling elites, nor did they want to confine themselves by referring unduly to the working class or even

20 See esp., Jürgen Kocka, "Sozial- und Wirtschaftsgeschichte", in Sowjetsystem und demokratische Gesellschaft. Eine vergleichende Enzyklopadie, vol. VI (Freiburg, Basel and Vienna, 1972), esp. pp. 2-39; Hans-Ulrich Wehler, Geschichte als historische Sozialwissenschaft (Frankfurt, 1973); Jürgen Kocka, "Sozialgeschichte - Strukturgeschichte - Gesellschaftsgeschichte", Archiv filr Sozialgeschichte, 15 (1975), pp. 1-42; idem, "Theorien in der Sozial- und Gesellschaftsgeschichte. Vorschläge zur historischen Schichtungsanalyse", Geschichte und Gesellschaft, 1 (1975), pp. 9-42; Hans-Ulrich Wehler, Modemisienungstheorie und Geschichte (Göttingen, 1975); idem, "Voruberlegungen zu einer modemen deutschen Gesellschaftsgeschichte", in Dirk Stegmann, Bernd-Jurgen Wendt and PeterChristian Witt (eds), Industrielle Gesellschaft und politisches System. Beiträge zur politischen Sozialgeschichte, Feseschrift fïr Fritz Fischer zum 70. Geburtstag (Bonn, 1978), pp. 320; Jürgen Kocka, "Sozialgeschichte, Gesellschaftsgeschichte", in Klaus Bergmann (ed.), Handbuch der Geschichesdidakrik I (Dusseldorf, 1979), pp. 130-143; Hans-Ulrich Wehler, "Anwendung von Theorien in der Geschichtswissenschaft", in Jürgen Kocka and Thomas Nipperdey (eds), Theorie und Erzahlung in der Geschichte (Munich, 1979), pp. 17-39.

21 Kocka and Wehler reviewed the US model via its adaption by West German social scientists. See esp., Wolfgang Zapf (ed.), Theorien des sozialen Wandels (Cologne and Berlin, 1969); idem/Peter Flora, "Zeitreihen als Indikatoren der Modernisierung", Politische Vierseljahrsschrift, 12 (1971), pp. 53-102; Peter Flora, Modernisierungsforschung. Zur empirischen Analyse der gesellschaftlichen Entwicklung (Opladen, 1974); idem, "Die soziologische Theorie der Modernisierung", Soziale Welt, 26 (1975), pp. 211-226.

2 Kocka, Sozial. und Wirtschafisgeschichte, esp. p. 33.

${ }^{2}$ Hans-Ulrich Wehler, Historische Sozialwissenschaft und Geschichtsschreibung. Studien zu Aufgaben und Traditionen deutseher Geschichtswissenschaft (Göttingen, 1980), pp. 111ff.

24 Hans-Ulrich Wehler, Krisenherde des Káaserreichs 1871-1918. Studien zur deutschen Sozial- und Verfassungsgeschichte (Gottingen, 1970), p. 325. 
the labour movement. In the last resort, this West German variant of the modernization model claimed an unrestricted sphere of activity for the ambitions of the more or less "non-institutional", social-liberal intelligentsia of the 1970s. Wehler's typification of dichotomies in "modernity" and "tradition"2s were, however, especially questionable, as they were supposed to isolate single indicative factors in the transition to developed capitalism and enable the testing of their potential modernization content. In this respect, Tipps' vehement critique was not taken to heart, namely that modernity/tradition represent asymmetrical concepts: as soon as "modernization" is used as an historical ideal, everything else which does not correspond to it is excluded as "traditional".26 The hint given by North American historians that the newest intellectual progressive utopia can be traced back to Herbert Spencer's Social-Darwinist premisses ${ }^{27}$ was not registered by the leading lights of German social sciences, even critical reflections from within their own ranks concerning the Janus-like consequences of "modernization" did not impair the ardour of the Bielefeld protagonists in propagating their faith in a form of historical progress tempered by state intervention measures. ${ }^{28}$

This mixture of critical reflection and deterministic standardization was also evident in the debates in the mid-1970s concerning attempts to transport the methodological stimuli of Kocka and Wehler into research concepts for the history of German fascism. The initiatives did not get very far, as the normative limits of the model manifested themselves on application. When Horst Matzerath and Heinrich Volkmann introduced a model for a quantitative investigation of the relationship between National Socialism and "modernization" at an historians' conference in 1975, it met with a mixed reception. The deficits criticized were: no comparative approach, overemphasis of normative elements, and the questionable transmission of the development problems of pre-industrial/

2s See the argument in Wehler, Modernisierungstheorie, pp. $14 \mathrm{ff}$.

${ }^{26}$ Dean C. Tipps, "Modernization Theory and the Comparative Study of Societies: A Critical Perspective", Comparative Studies in Society and History, 15 (1973), pp. 199-226. See also, Joseph R. Gusfield, "Tradition and Modernity: Misplaced Polarities in the Study of Social Change", American Journal of Sociology, 72 (1967), pp. 351-362.

"See esp., Ali A. Mazni, "From Social Darwinism to Current Theories of Modernization", World Politics, 21 (1968), pp. 69-83; S. J. Bodenheimer, "The Ideology of Developmentalism", Berkeley Joumal of Sociology, 35 (1968), pp. 130-159; D. J. Y. Peel, "Spencer and the Neo-Evolutionists", Sociology, 3 (1969), pp. 173-191; Robert M. Lauer, "The Scientific Legitimation of Fallacy: Neutralizing Social Change Theory", American Sociological Review, 36 (1971), pp. 881-889.

${ }^{23}$ Imanuel Gries, "Prometheus und Pandora. Zur Stellung der industriellen Revolution in der Weltgeschichte", in Industrielle Gesellschaft und politisches System, pp. 21-36. Cf. the critique of modernization and German historians in: Gunther Schufer, Modemisienung der Vergangenheit. Geschichtswissenschaft in der Industriegesellschaft (Hamburg, 1990). 
agrarian societies to developed industrial societies, etc. ${ }^{29}$ Above all, the objection raised by the social scientist Jens Alber was of foremost importance. At the end of the 1980s Alber confronted the "modernization theory" with its functional context, using indicators borrowed from US development sociology and thus contributing significantly to the debate. ${ }^{30}$ He proved that no socio-economical modernizing effects - in the framework of a capitalistic-democratic model of progress - grew out of the Nazi system. The model based on Alber's own indicators (urbanization, incomes structure, education, traditional family ties, gender roles, recruitment of elites, social and legal security, wage income, barriers to mobility) produced the following: the Nazi dictatorship was a specific response of the ruling elites to the world economic crisis. This variant - "solving" a crisis of the political system within a fully-developed "Moderne" - meant, in effect, a demodernization if one starts from the basis of the "capitalistic progress model".

The main currents in modern history studies were not, however, affected by this immanently methodological refutation. On the contrary, up to the mid-1980s Wehler's dichotomy-schema was used unreservedly to remove, above all, the social policy and planning decisions of the Nazis from their contexts. In addition, there occurred on the occasion of the fortieth anniversary of the defeat of German fascism and simultaneously with the "Bitburg affair"31 a spectacular attempt on the part of the then director of the Munich Institute for Contemporary History, Martin Broszat, ${ }^{32}$ to exploit the controversies current at the time for a re-evaluation of the history of the Third Reich. It is now time, wrote

2 Horst Matzerath and Heinrich Vollmann, "Modernisierungstheorie und Nationalsozialismus", Geschichte und Gesellschafi, Sonderheft 3: Theorien in der Praxis des Historikers (Gơttingen, 1977), pp. 86-116.

"Jens Alber, "Nationalsozialismus und Modemisierung", Kölner Zeitschrift für Soziologie und Sozialpyschologie, 41 (1989), pp. 346-365.

${ }^{31}$ Against the reservations of US diplomacy the West German Government insisted on carrying out a joint visit by President Reagan and Chancellor Kohl to a military graveyard in Bitburg/Eifel on the occasion of the 40th anniversary of the capitulation of the German Wehrmacht. The plans were not changed even after it had become known that soldiers of the Waffen-SS had also been buried there.

${ }^{32}$ Broszat was born in 1926 and studied modem history under Theodor Schieder in Cologne. He was awarded a Ph.D. in 1952 for a study on "volkisch" antisemitism in Germany. After a short period as a trainee teacher Broszat went in 1955 to the institute in Munich which he was later to lead. Broszat belonged to a group of middle-generation historians who won wide recognition for their empirical studies on the Nazi regime, thus helping to overcome the totalitarian doctrine prevalent in the 1950s. His adoption of an affirmative interpretation of German fascism using modernization theories came about only in the 1980s. See Martin Broszat, "Zur Struktur der NS-Massenbewegung", Vierteljahrshefte fïr Zeitgeschichte, 31 (1983), pp. 52-76; idem, Nach Hitler (Munich, 1986); idem, Introduction to: Martin Broszat, K. D. Henke and H. Woller (eds), Von Stalingrad zur Walirungsreform. Zur Sozialgeschichie des Umbruchs in Deutschland (2nd ed., Munich, 1989). 
Broszat in an essay which caused no little controversy, ${ }^{33}$ to begin a period of "historicization" - hitherto not attempted - of the years between 1933 and 1945. Broszat argued that the "morality of dismay" and presenting National Socialism "as a negative standard for political enlightenment" were long since redundant and had been pushed into the background by other catastrophes in world history. In future, one must absent oneself from black and white schemata and work out sophisticated, general historical models, in order to give due place of honour to those grey zones and blurred dividing lines which comprise a good part of all historical facts. Everything which emerged from the ruling apparat of the Nazis cannot be ascribed in all cases to the undoubtedly dreadful overall balance of the epoch. For example, the Deutsche Arbeitsfront worked out a general people's insurance plan with index-linked pensions guaranteed by the state and so contributed to "the social insurance legislation of the Federal Republic in the 1950s, a remarkable achievement for the time". ${ }^{34}$ Here one can see, Broszat continued, a proximity to the Beveridge plan, published during the war. These achievements, along with other improvements in social legislation, are evidence of an amazing "thrust of progressive social welfare innovations pursued by DAF, despite its rather manipulative and repressive functions." According to Broszat, such an example demonstrates that "the countless modernizing endeavours" between 1933 and 1945 "cannot be divested of historical significance just on the basis of being linked to the Nazi regime."

"Not everything that happened in the Nazi era and had historically far-reaching effects can be said to have merely served the dictatorial and inhumane power-objectives of the regime." By using arguments based predominantly on social policy, Broszat made clear in 1985 in which direction his "historicization" postulate was aimed and by drawing attention to allegedly social-progressive elements, the Nazi dictatorship was to be reclaimed for the "Moderne" and should take its place in the continuum of the development towards the German social state. With this conceptual fixation, Broszat's "historicization" postulate comprised in the intervening years a core ingredient of German historical revisionism. ${ }^{35}$

When we examine the main "historicizing" argument of Broszat's, namely DAF ("social support of the German people") on the basis of its planning documentation and similar material, we reach the conclusion that we are dealing with mystification. The "social support", a social and political programme for post-war Germany, was used during the war as a camouflaged national loan to siphon off purchasing power in

${ }^{33}$ Martin Broszat, "Pludoyer für eine Historisierung des Nationalsozialismus", Mferkur. Deutsche Zeitschrift fur europaisches Denken, 39 (1985), no. 5, pp. 373-385.

It Ibid., p. 383. The following quote: ibid., pp. $383 f$.

${ }^{35} \mathrm{Cf}$. Uwe Backes, Eckhard Jesse and Rainer Zitelmann, "Was heißt 'Historisierung' des Nationalsozialismus?" in idem, Die Schatten der Vergangenheit. Impulse zur Historisienung des Nationalsozialismus (Frankfurt and Berlin, 1990), pp. 25-57. 
Order to kick-start the economies of the conquered European countries after a German victory. ${ }^{36}$ Under this premiss, a socio-politic austerity course, retained since the period of emergency laws passed by the presidential cabinets in the Weimar Republic, was to be adjusted by means of socio-racist measures to the conditions of a transformed society enjoying full employment. Concerning the expected compensation for the vicissitudes befalling wage earners, all eventualities were to be guarded against - none, however, that might lead to egalitarian social insurance for all. Only "Germans" and "persons of German blood" were to receive the blessings of this "social support", ${ }^{37}$ but not, however, the millions of foreign workers and those in forced labour who had until then enjoyed the benefits of the Reich's social security system, albeit often formally and on the basis of their "racial origin". But also for migratory workers entitled to claim benefit in the "competitive society" there were preconditions which ran contrary to normal capitalist-parliamentarian concepts of social policy: general compulsory labour up to 65 years and over; exclusion from the system for "malingerers" and "strikers" after sentencing by the justice authorities or "social courts of honour". The model was based on cost calculations which had place neither for the "rearing of inferior humans" nor the "building of institutions for idiots". ${ }^{38}$ These socio-political models of reorganization were linked closely with general conscript labour and socio-racist extermination technology. They also represented a consciously formulated rejection of all previous development tendencies in capitalistic social policy as it had been understood in the modernization theories of West German social historians.

Taking the background of power politics into account, Broszat's attempts at "historicization" proved to be an ideological construction which made a critical historicization impossible. His desire to present an affirmative historicization of the most significant showpiece of fascist social planning can certainly be traced back to an inadequate knowledge of the source materials, to methodological mistakes and to analogies which cannot be drawn. These inconsistencies on the part of such a skilled and empirically competent expert such as Broszat can, in the last resort, only be explained by external pressure exerted on him to conform. What he does not offer is a critical analysis of the above-mentioned model, which was designed by the Nazis to reorganize and radicalize

\footnotetext{
${ }^{36}$ See Karl Heinz Roth, Intelligenz und Sozialpolitik im "Dritten Reich". Eine methodischhistorische Studie am Beispiel des Arbeitswissenschaftlichen Instituts der Deutschen Arbeitsfront (Munich [etc.], 1993).

${ }^{3}$ Arbeitswissenschaftliches Institut der Deutschen Arbeitsfront [abbr.: Awi der DAF], Die Altersversorgung (Berlin, 1940), B1. 4, 23ff., 30, 39, 50. Reproduced in Hamburger Stiftung für Sozialgeschichte des 20. Jahrhunderts (ed.). Sozialstrategien der Deutschen Arbeitsfront (Munich [etc.], 1988), part B/dept. 2, fiche 6, Denkschrift no. 8.

38 Ibid., Bl. 4.
} 
socio-political power structures. Instead, the model is removed from its context and presented in such a way that it could be inserted in the positive scale of values associated with long-term continuity in modernization concepts.

\section{FROM THE CRISIS OF HISTORIOGRAPHICAL THEORY TO THE MODERNIZATION MYTHS OF THE NEWV RIGHT}

In the meantime, the New Right in West Germany have latched fully on to the deficits evident in the modernization debate and constructed a new ideological syndrome from them. The right-wing apologists have taken some aspects from the 1960 s debate (Dahrendorf/Schoenbaum/ Turner) on board, especially the selection of the "social-revolutionary" elements, while at the same time rejecting the reference to ultimately "anti-modernist" final goals. Similarly, they picked out the reductionist system of dichotomies in the theoretical offerings of Kocka and Wehler and threw overboard the complex attempt of the duo to relativize, in a critical and social-reformist sense, the North American hegemony model. In a skilful move, the New Right's exponents also adhere to Broszat's "objectivization" postulate, while simultaneously issuing a declaration of war against the antifascism of the post-war German Left and that of the 1968 generation. ${ }^{39}$ In a review of the five years' activities of the up-and-coming young historians of the New Right two phases become evident: the first one served as an orientation for Nolte's disciples and "extremism researchers" from the Federal Ministry for the Interior and its environs and lasted until 1991. In the second period social historians attempted to undermine the paradigms of their subject and press it into the service of propagating modernization myths.

The most influential revisionist in questions pertaining to the social politics and history of the Nazi dictatorship is, without doubt, Rainer

30 The most important attacks against antifascism since the beginning of the 1990s are: Herbert Ammon, "Antifaschismus im Wandel? Historisch-kritische Anmerkungen zur Aktualitat eines Begriffs", in: Backes, Jesse and Zitelmann, Was Heißt "Historisierung", pp. 568-594; Bundesministerium des Inneren (ed.), Bedeutung und Funktion des Antifaschismus (Bonn, 1990); Berndt Rabert, "Terrorismus und Antifaschismus. Der MiBbrauch des Faschismusvorwurfs durch die deutschen Linksterroristen 1970-1976", in Hans-Helmuth Knultter (ed.), Antifaschismus als innen- und aupenpolitisches Kampfminel. Studien und Berichse aus dem Seminar für Politikwissenschaft der Universitat Bonn, no. 2 (1991), pp. 77ff.; Hans-Helmuth Knutter, "Antifaschismus und politische Kultur in Deutschland nach der Wiedervereinigung", Aus Politik und Zeitgesehichte, Beilage zur Wochenzeinung Das Parlament, 9 (1991); idem, Die Faschismuskeule. Das letzte Aufgebot der deutschen Linken (Berlin and Frankfurt, 1993); Manfred Kittel, Die Legende von der "Zweiten Schuld", Vergangenheitsbewaltigung in der AYa Adenauter (Berlin and Frankfurt, 1993); Antonia Grunenberg, Antifaschismus - ein deutscher Mfythos (Reinbek bei Hamburg, 1993); Klaus Hornung, Das totalitäre Zeitalier. Bilanz des 20. Jahrhunderss (Berlin and Frankfurt, 1993), pp. $267 f$. 
Zitelmann. Seven years ago he completed his dissertation (Darmstadt), in which he threw light on Hitler's system of thought by using the dictator's writings and those written about him. ${ }^{\text {to }}$ Accordingly, Hitler was a social revolutionary in a genuine sense; he strove consciously and systematically for a modernization of society and did not do so involuntarily in the prosecution of his backward-looking goals, as stated by Dahrendorf, Schoenbaum and Turner. Starting from some SocialDarwinist basic views, the "Fürer", in Zitelmann's eyes, committed himself to more equality of opportunity in the "national community" and egalitarian social policies, and spoke in favour of a levelling process in a post-bourgeois society marked by social advancement and performance-orientation. This "modernism" was truly Hitler's ultimate goal, and in attaining it, he employed an expansionist foreign policy ("Lebensraum"), especially in the East." As we see, Zitelmann had merely turned the means-and-ends dichotomy of the prevailing modernization concept right round, thereby generalizing the impulse offered by Broszat. Zitelmann linked these methodological steps with a reinterpretation of the conventional revolution concept which he borrowed from Ernst Nolte. ${ }^{42}$ From the politically suspect "normative" aspects of revolutionary history Zitelmann separated the "empirical" ones and identified them with long-term modernization trends from US sociology, then transmitting them to the period of the Nazi dictatorship. Now the Nazi era was presented as part of a global "fundamental revolution" in modernization. These intellectual outpourings were underlaid exclusively with historical ideas - by falling back on the "phenomenological selfwriting" of Hitler's world of ideas. In the case of so much methodological and ideological reductionism, a far-reaching identification with the subject under investigation (Hitler) could not fail to materialize. Hitler's remarks concerning the mobilization of social-imperialistic sentiment in order to compensate the lower classes for the fact that their social advancement was still being blocked is re-evaluated as being an expression of more "equality of opportunity" - a concept Hitler demonstrably never used. All axioms central to "modernization" are derived from this semantic counterfeit: "social mobility", "egalitarian tendencies in social policy", "social welfarism", etc. In the course of this questionable argumentation untold violence is also done to the source materials so that Hitler's alleged social levelling strategy can be divested of its violent, destructive and inhumane content.

\footnotetext{
*o Rainer Zitelmann, Hitler. Selbstverständnis eines Revolutionars (2nd revised and enlarged Ed., Stuttgart, 1989).

"t Rainer Zitelmann, 'Zur Begrundung des 'Lebensraum' - Motive in Hitlers Weltanschauung", in Wolfgang Mlichalka (ed.), Der Zweire Welikrieg. Analysen - Grundzilge Forschungsbilanz (2nd ed., Munich and Zurich, 1990), pp. S51-567.

"2 Rainer Zitelmann, "Die totalitsre Seite der Moderne", in Mlichael Prinz and Rainer Zitelmann (eds), Nationalsozialismus und Modernisierung (Darmstadt, 1991), pp. 1-20.
} 
It is therefore all the more astonishing and worthy of explanation that Zitelmann's book, published in 1987 and in an enlarged edition two years later, was enormously successful. The explanation is simple: Zitelmann turned a key-model designed by leading historians 180 degrees around and claimed it for the New Right. Ultranationalistic journalists became his imitators, his ideas were described as being like a reissue of the "German Socialism" of Gregor Strasser, ${ }^{43}$ and the social question was made an integral part of neo-racist, right-wing extremism. Zitelmann subsequently worked at the Free University in Berlin, from 1992 in the publishing house of Ullstein/Propyläen and attracted a group of young revisionists, who, from different starting-points, all strove to popularize a new view of history. At first there was collaboration with other biographer-historians, who supplemented the "revolutionized" portrait of Hitler à la Zitelmann with further "representatives of social progress" from within the NSDAP leadership (Franz W. Seidler on Fritz Todt, Ronald Smelser on Robert Ley, and later, Gerhard Paul on Josef Bürckel as a type of "red" Gauleiter). 4 Afterwards there was also cooperation between Zitelmann and the young political scientists and historians who had previously worked in "extremism/ terrorism" research projects funded by the Federal Ministry of the Interior. They attacked the "antifascist syndrome" of the New Left, thus removing an essential barrier to the "national" integration of right-wing extremism (Herbert Ammon, Uwe Backes and Eckhard Jesse). 4 Zitelmann heads a department in the newspaper Die Welt (Springer concern) since December 1993 and is determined, with his comrades-in-arms, some of whom even come from the SPD, the unions and the "Bündnis 90/Grünen", to win over the complete

${ }^{13}$ See esp. the publications of the former functionary of the Hitler Youth Klaver: Max Kluver, Vom Klassenkampf zur Volksgemeinschaft. Sozialpolitik im Dritten Reich (Leoni am Starnberger See, 1988).

4 Franz W. Seidler, Fritz Todt. Baumeister des Dritten Reiches (Munich, 1986); Ronald Smelser, Robert Ley - Hitlers Mann an der "Arbeisfront". Eine Biographie (Paderborn, 1989); idem. "Robert Ley - der braune Kollektivist", in idem and Rainer Zitelmann (eds), Die braune Elite. 22 Biographische Skizzen (Darmstadt, 1989), pp. 173-187; Gerhard Paul, "Josef Burckel - Der rote Gauleiter", in Ronald Smelser, Enrico Seyring and Rainer Zitelmann (eds), Die braune Elite II. 21 weitere biographische Skizzen (Darmstadt 1993), pp. 51-65.

${ }^{43}$ See footnote 39. Since 1989 Backes and Jesse edit a yearbook ("Extremismus und Demokratie") which has proved to be a successful addition to the publications issued by revisionist publishers (Ullstein/Propylăen, Siedler, Universitas/Herbig).

to For example: Brigitte Seebacher-Brandt, Willy Brandt's widow, Tilman Fichter, assistant to the executive of the metalworkers' union, Wolfgang Kowalsky, and Wolfgang Templin, who was active in the civil rights movement in the GDR. Their most important historicalrevisionist tracts: Tilman Fichter, Die SPD und die Nation. Vier sozialdemakratische Generationen zwischen nationaler Selbstbestimmung und Zweistaatlichkeit (Berlin and Frankfurt, 1993); Walter Kowalsky, Kulturrevolution? Die Neue Rechte in neuen Frankreich 
conservative spectrum of the ruling elites for an extreme right-wing transformation of traditional history. ${ }^{47}$

The second phase of this campaign began in 1991 with the publication of an anthology edited by Zitelmann and a former pupil of Kocka's, Michael. Prinz. ${ }^{48}$ Now the sluice gates were opened, more and more aspects of the Nazi dictatorship "examined", mosaic pieces of so-called "social progressivity" collated in order to transform completely the conventional historical opinion on the structure and social policies of the Nazi regime. The NSDAP itself underwent a metamorphosis and became, finally, the first "popular party of protest" (Jürgen W. Falter). ${ }^{49}$ A "double modernization" relating to the period before and after 1945 was bestowed on education, science, town planning, psychiatry, the school system, etc. ${ }^{30}$ The fact that officers with a technical background serving with the Nazi forces were given promotion outside the previous caste-system of the officer corps was interpreted as an indication of egalitarian tendencies within the Wehrmacht. ${ }^{s 1}$ The experts in structural history from the Bielefeld school now came into their own: they ransacked the complex theoretical edifices of their teachers, disposed themselves of the latters' social-liberal intentions and implanted all historical fields of study in the procrustean bed of dichotomies and stratified modernization trends. Willi Oberkrome distanced himself from the warmongering and racist goals of fascist "national customs and traditions", but described the methods employed to promote tradition as an

und ihre Vorläufer (Opladen, 1991); idem, "Die Vergangenheit als Krux der Linken. Zur Auseinandersetzung um 'antifaschistische' Strategien und die 'nationale Frage' ", in Backes, Jesse and Zitelmann, Was heißt "Historisienung", pp. 595-613; Brigitte Seebacher-Brandt, Die Linke und die Einheit (Berlin, 1991).

"At the beginning of March 1994 the staff of the Springer newspaper Die Welt protested against the writing of department head Zitelman in his Saturday column "Geistige Welt", which they saw as a right-wing escalation of the paper's conservative course. Zitelmann defended himself against the charges, and also received solidarity addresses - documentary testimony of the upsurge of intellectual right-wing extremism in Germany in the 1990s. But he was not successful, and had to retreat from Die Welt in May 1994.

t8 Michael Prinz and Rainer Zitelmann (eds), Nationalsozialismus und Mlodernisierung (Darmstadt, 1991).

49 Jurgen W. Falter, "War die NSDAP die erste deutsche Volkspartei?", in Prinz and Zitelmann, Nationalsozialismus und Modemisienung, pp. 21-47; idem, Hitlers Walzler. Die Anhanger der NSDAP 1928-1933 (Munich, 1991). Eight years ago Falter published his thesis that the workers became the most important supporters of Hitler's dictatorship: Jürgen W. Falter, "Warum die deutschen Arbeiter wahrend des 'Dritten Reiches' zu Hitler standen", Geschichte und Gesellschaft, 13 (1987), pp. 217-231.

so Rolf Messerschmidt, "Nationalsozialistische Raumforschung und Raumordnung aus der Perspektive der 'Stunde Null' ", in Prinz and Zitelmann, Nationalsozialismus und Mlodernisierung, pp. 117-138; Hans-Walter Schmuhl, "Reformpsychiatrie und Massenmord", ibid., pp. 239-266; Franz Sonnenberger, "Die vollstreckte Reform - Die Einfuhrung der Gemeinschaftsschule in Bayern 1935-1938", ibid., pp. 172-198.

"Bermhard R. Kroener, "Strukturelle Veränderungen in der militarischen Gesellschaft des Dritten Reiches", ibid., pp. 267-296. 
innovatory contribution to broadening the "progressive" overall balance. ${ }^{52}$ Michael Prinz busied himself with the balance of Nazi social policy itself. ${ }^{33}$ According to him, the "Law for the Regulation of National Labour" (1934) was indeed reactionary from the workers' point of view, but "ahead of its time" (at the point of application). The social status of women, too, underwent considerable improvement in the sense that their double functions as production and reproduction workers became stabilized. Despite all racist distortions, the social policies of the Weimar Republic were long-lived and contributed - see, for example, DAF to a remarkable rise in economic efficiency. The DAF, reluctantly pressed into carrying out trade union functions, clawed back concessions from industry to an extent hitherto unknown. Without doubt, the costs of the "modernization push" were inordinately high. None the less, the benefits accruing from it were "new freedoms". The ensuing and enormous homogenization tendency within social structures is irrefutable today and must lead to a new overall evaluation of the epoch. So much for the revisionists' case. By taking the main lines of argument in social history scholarship, by trimming and distorting them beyond recognition, the revisionists are able to erect a system of "scientific" rehabilitation by these and other means of shameless historical propaganda.

\section{THE IDEOLOGY OF "NATIONAL COMMUNITY"}

The modernization theory of the New Right asserts that German fascism completely destroyed the social milieu(x) of the working class and, in a revolutionary upheaval in society, integrated wage earners into the "national community". ${ }^{\text {st }}$ These findings were bound to find favour with empirically-minded colleagues, considering that they had been confronted with the propagandistic hagiography from the GDR to the effect that

32 Willi Oberkrome, "Reformansătze in der deutschen Geschichtswissenschaft der Zwischenkriegszeit", ibid., pp. 216-238; idem, Volksgeschichte. Methodische Innovation und volkische Ideologisienung in der Geschichtswissenschaft 1918-1945 (Göttingen, 1993). Kocka had earlier presented his Ph.D. student Oberkrome with a detailed model of this interpretation: Jügen Kocka, "Ideological Regression and Methodological Innovation: Historiography and the Social Sciences in the 1930s and 1940", History \& Memory, 2 (1990), pp. 130-137.

${ }^{33}$ Michael Prinz, "Die soziale Funktion moderner Elemente in der Gesellschaftspolitik des Nationalsozialismus", in Prinz and Zitelmann, Nationalsozialismus und Modermisierung, pp. 297-327. Initially, Prinz tried to prove the effects of the modernizing function of the Nazi dictatorship in a specific field. In his Ph.D. (1986) he stated that the differences in social status between workers and white-collar employees had lessened under Nazism - a typical example of holding that Nazi propaganda reflected social reality. See Michael Prinz, Vom neuen Mtittelstand zum Volksgenossen. Die Entwicklung des sozialen Stanus der Angestellten von der Weimarer Republik bis zum Ende der NS-Zeit (Munich, 1986). st Dahrendorf, Gesellschaft und Demokratie, pp. 431ff. Despite all criticisms issued since then, Dahrendorf still sticks to his case. See idem, Der moderme soziale Konflikt. Essays zur Politik der Freiheit (Stuttgart, 1992). 
the working class, under the leadership of the German Communist Party (KPD), had carried out broad resistance to Nazi oppression. ${ }^{55}$ In addition, many regional or specific studies had produced evidence of the contrary. Since the beginning of the 1980s these developments gave weight to the increasingly popular thesis that while the middle class had brought Hitler to power, the workers had kept him there. ${ }^{56}$ Finally, a conventional wisdom emerged and proceeded to exclude the history of resistance to fascism from the structural history of the working class. In this respect, highly selective and methodologically questionable series of biographical interviews were presented as representing class-identity in its entirety. ${ }^{57}$ To the same end, single events ${ }^{58}$ or election results were generalized without analytical exactitude. ${ }^{39}$ Also taken at face value was the unprecedented level of propaganda under the Nazi dictatorship ("second reality") when it proclaimed the integration of the "toiling masses". ${ }^{60}$ In using Tim Mason's example, I will apply myself to the question of where the historical truth lies between the two extremes of resistance myths and integration legends. For the moment, however, I want to emphasize once more that in many cases the methodological premisses of the New Right's modernization theories have deformed the extremely complex problems of the history of labour during the Third Reich beyond recognition.

\section{SOLIDARITY WITH A RENEWED CONCEPT OF A POWERFUL PRUSSIAN-GERMAN STATE}

In the meantime, the present school of revisionist historians, whose argumentation ran for a long period on socio-political lines, have gained

9s This approach becomes even more implausible in view of the fact that GDR historiography more or less ignored social and structural aspects of the history of the German working class during Hitler's rule.

so See esp. Gunther Mai, "Warum steht der deutsche Arbeiter zu Hitler?' Zur Rolle der Deutschen Arbeitsfront im Herrschaftssystem des Dritten Reiches", Geschichte und Gesellschaft, 12 (1986), pp. 212ff. This programmatic approach has since become more radical and part of the revisionists" arsenal: See Gunther Mai, "Atbeiterschaft zwischen Sozialismus, Nationalismus und Nationalsozialismus. Wider găngige Stereotype", in Backes, Jesse and Zitelmann, Die Schatten der Vergangenheit, pp. 195-217.

"Lutz Niethammer, "Die Jahre weiß man nicht, wo man die heute hinsetzen soll". Faschismuserfahnungen im Ruhrgebiet (Berlin and Bonn, 1983).

ss For example the interpretation of the elections of factory staff representatives in the years 1934-1935, which does not hold up to examination either on statistical or source grounds. Cf. Wolfgang Zollitsch, "Die Vertrauensratswahlen von 1934 und 1935. Zum Stellenwert von Abstimmungen im 'Dritten Reich' am Beispiel Krupp", Geschichte und Gesellschaft, 15 (1989), pp. 361-381.

s9 Falter draws unjustifiable conclusions from sparse data: Falter, "War die NSDAP die erste deutsche Volkspartei?".

${ }^{\infty}$ The reversal of propaganda and reality is especially crass in Klaus-Michael Mallmann and Gerhard Paul, Herrschaft und Allag. Ein Industricrevier im Dritten Reich (Bonn, 1991), esp. pp. 114ff. 
new terrain. For the group around Zitelmann the capitulation and ensuing incorporation of the GDR into the West German state was the signal to publicize the theories of their academic teachers with power politics arguments. ${ }^{61}$

In contrast to the "Historikerstreit" of $1986 / 1987$, the Young Turks went unopposed this time. True, they did play on different instruments, but by now have achieved an orchestration of their own, mainly by referring to the so-called "conservative revolution" in the Weimar Republic. ${ }^{62}$ On the other hand, they have systematically applied a policy of removing any further obstacles in their way by employing socialrevolutionary demagoguery, for example by adhering to the new "cultural-ideological" defensive thesis of Ernst Nolte in connection with fascist mass extermination policies. ${ }^{63}$ They have furthermore rediscovered Prussian-German state power, which now - so they argue - dominates Central Europe once more. ${ }^{64}$ The argument goes further: the supranational integration of Europe on the basis of the Maastricht Treaty has become superfluous, as the abrupt end of the "global civil war" has placed the priority of the "national struggle for existence" on the agenda once again. ${ }^{65}$ German power politics is "recalled" to historical greatness, it must free itself from "French dictation"; 66 German politics has new missions to fulfil because of the country's geographical position, especially on the restless eastern borders of the former Reich. ${ }^{67}$ The New Right holds that before one gets involved in another "Watch on the Oder" to contend with the predictable and permanent ungovernability of "Middle

${ }^{61}$ Solidarity with Nolte's view is evident in Rainer Zitelmann, "Nationalsozialismus und Antikommunismus. Aus AnlaB der Thesen von Ernst Nolte", in Backes, Jesse and Zitelmann, Die Schatten der Vergangenheit, pp. 218-242.

62 For background and doctrine of the "conservative revolution" (Arthur Moeller van der Bruck, Ernst Jünger, Max Hildebert Boehm, Oswald Spengler, etc.) see Joachim Petzold, Wegbereiter des deutsehen Faschismus. Die Jungkonservativen in der Weimarer Republik (2nd ed., Cologne, 1983).

s See Ernst Nolte, Geschichesdenken im 20. Jahrhundert. Von Max Weber bis Hans Jonas (Berlin, 1991), pp. 329ff.

o Karlheinz WeiBmann, Rucknf in die Geschichte. Die deutsche Herausforderung. Alte Gefahren - Neue Chancen (Berlin and Frankfurt, 1992); Rainer Zitelmann, Karlheinz WeiBmann and Michael GroBheim (eds), Westbindung. Chancen und Risiken fur Deutschland (Frankfurt and Berlin, 1993).

os Ludwig Watzal, "Der Irrweg von Maastricht", in Zitelmann, Weißmann and Großheim, Westbindung, pp. 477-500.

os Resuscitating the French "arch enemy" is one of the most amazing properties of modem German historical revisionism. The most important element that triggered off this new-old resentment was the opposition the French Government offered in summer 1991 to the support given by Germany and Austria to separatism in Croatia and Slovenia.

${ }^{67}$ Economic penetration has replaced the military strategy of the Germans in the 1930s, as the case for the inclusion of former German territories (East Prussia, Upper Silesia) in the European Community shows. Cf. Arnulf Baring, Deutschland, was nun? (Berlin, 1991); Ansgar Graw, Der Freiheitskampf im Baltikum (Erlangen, Bonn and Vienna, 1991); idem and Wilfried Boehm, Königsberg morgen. Luxemburg an der Osssee (Asendorf, 1993). 
Europe", it makes more sense first to discard the lilliputian aims of former German foreign policy ${ }^{68}$ and to participate without illusions in the rigorous planning of a reconstructed "Eurasia", giving ample thought to hegemony over the newly emerged small states of Eastern and SouthEastern Europe.

Passages of this kind can be read in the publications of the renowned Ullstein publishing house, where Zitelmann has been working as a leading editor for the past few years. Historical writings with a similar revisionist message are also issued by Siedler-Verlag ${ }^{69}$ and receive official government recognition. ${ }^{70}$ All these tendencies can be associated closely with a general offensive against the entire social history scholarship of the 1970s. It is high time, the Right argues, for the social historians of the 1970 s to vacate their prominent positions; the "priority of German home affairs" demands their removal if the emphasis of German historical science is to manifest itself by dealing with problems of international relations. ${ }^{11}$ Established historians look on from the sidelines or prepare themselves for new tasks - their contribution to the "rewriting" of the history of the GDR has already produced disastrous results. ${ }^{72}$ With a few exceptions, ${ }^{73}$ the leading exponents of German historical studies have kept silent about the misappropriation of their methodological paradigma; silent, too, when these models are integrated into the "strong state" concept which now enjoys increasing social acceptance and threatens to condemn critical historiography about the Nazi dictatorship to oblivion.

\section{FASCIST GENOCIDE AS THE STARTING-POINT FOR THE CONSTRUCTION OF A "NEGATIVE" MODERNIZATION THEORY}

In the epistemological models used to provide an historical reconstruction of the Nazi dictatorship and examined in these pages, an analysis of

\footnotetext{
6s Here the historical revisionists borrow from the arguments of the conservative political scientist Hans-Peter Schwarz, who accused the Germans, in a reaction against the "power obsession" of the fascist era, now to have gone to the other extreme and forgotten what power means. See Hans-Peter Schwarz, Die gezähmten Deutschen. Von der Machtbesessenheit zur Machtvergessenheit (Stuttgart, 1985); idem, "Das Ende der Identitütsneurose", Rheinischer Merkur, 7 September 1990.

${ }^{69}$ Since then the publications of Siedler also call for the revision of Germany's eastern borders: See: Hartmut Boockmann, Ostpreußen und Westpreußen (Berlin, 1992); Friedrich Prinz, Bohmen und Mahren (Berlin, 1992).

7 Alfred Schickel, a revisionist historian and head of a modern history research centre in Ingolstadt, received a government medal: "Notizen aus der WissenschaftspolitikBundesverdienstkreuz für cinen revisionistischen Historiker", 1999, 8 (1993), no. 3, pp. 125-128.

7 Gregor Schöllgen, Angst vor der Macht. Die Deutschen und ihre Außenpolitik (Berlin and Frankfurt, 1993).

7 The colonization of East German scientific institutions is documented regulatly in: 1999. "Notizen", volumes 1991ff.

73 Especially the historians' school founded by Hans Mommsen (footnote 87).
} 
mass extermination practices found no place. The very fact of the mass murders is sui generis a provocation to the proponents of theories of "modernization" and "national community". Therefore, they play down the entire subject ${ }^{74}$ or exclude it. If it is considered at all, genocide is afforded a minor role in the accumulatively vicious internal wranglings of the Nazi elites and, at the most, analysed merely at the highest decision-making level. This model-conditioned exclusion has the inverse consequence that in researching the background to, and the actual steps taken, in executing the genocide policy, the totalitarianism concept still goes unchallenged and is constantly widened by new facets. ${ }^{75}$ The mass liquidation of institutionalized patients, Jews, gypsies, Soviet POWs and "elements" deemed outside the "community" is interpreted as a singular lapse on the part of a civilized people, a lapse which developed out of the immanent logic of totalitarian rule, and, as a consequence, can be explained solely on these terms or with reference to the regime's racist ideology. The Nazi murder-machine is thus presented as a kind of "black box" outside historical comprehension, ${ }^{76}$ provided one leaves aside the ahistorical generalization of racism and antisemitism as eternal problems. According to the revisionists, fascist mass murder also defies comprehension because the victims could not understand it either and it is improper to take a different point of view than that of the victims.

Sometimes the tendency to link totalitarianism theories with conceptions of modernization is clear. In this respect, the studies of the ex-Communist sociologist Zygmunt Bauman are beginning to attract disciples. ${ }^{n}$ Bauman states that fascist genocide and all other genocidal events of the twentieth century are compellingly logical and simultaneously immanent consequences of the bureaucratic-modernization process going on since the eighteenth century and analysed by Max Weber. The modernization model thus returns in a different garb and as a negation of itself. The levelling effects of totalitarianism theories can be found not only in the practice of indiscriminately placing Nazi concentra-

74 I cannot adumbrate the revisionist literature on the so-called "Auschwitz-lie" here for reasons of space.

75 Especially at a time when the totalitarianism model plays an important part in the "revisionism" discussion. See Karl Dietrich Bracher, Die Totalitare Erfahrung (Munich and Zurich, 1987); Uwe Backes and Eckhard Jesse, "Totalitarismus und Totalitarismusforschung - Zur Renaissance einer lange tabuisierten Konzeption". Jahrbuch Extremismus \& Demokratie, 4 (1992), pp. 7-27; Klaus Hornung, Das totalitäre Zeitalter. Bilanz des 20. Jahrhunderts (Berlin and Frankfurt, 1993).

${ }^{76}$ Dan Diner (ed.), Zivilisationsbruch. Denken nach Auschwitz (Frankfurt, 1988); idem, "Zwischen Aporie und Apologie. Uber Grenzen der Historisierbarkeit des Nationalsozialismus", in idem (ed.). Ist der Nationalsozialismus Geschichte? Zur Historisierung und Historikerstreit (Frankfurt, 1988).

$n$ Zygmunt Bauman, Modernity and the Holocaust (Ithaca, NY, 1989). German edition: Dialektik der Ordnung. Die moderne und der Holocaust (Hamburg, 1992); idem, Moderne und Ambivalenz. Das Ende der Eindeutigkeit (Hamburg, 1992). 
tion camps and Soviet Gulags on the same level, ${ }^{78}$ but also in the statement that Leninism-Stalinism is the very incarnation of the "Moderne". ${ }^{79}$ In connection with a totalitarianism model tailored for the history of the two German states established in $1949,{ }^{80}$ the negative modernization theory is fast gaining ground within those currents in German historiography and social sciences which had least contact with the hegemony claims of the revisionists in recent years. A social sciences institute in Hamburg plans to hold a series of conferences on this connex (totalitarianism-modernization) in the coming months. ${ }^{81}$ At the same time, the level of conceptual abstraction evident in writings about the negative modernization theory is obviously on the increase. ${ }^{22}$ The culprits and victims of the Nazi genocidal extermination policy do not feature in such studies, neither do the actual socio-economic power structures which facilitated that policy. The justification for such omissions is that the concentration camp, as a laboratory for pure violence, precluded by its very nature interventions of any kind on the part of society as a whole. Another such example is the statement that slave labour in the concentration camps cannot be comprehended any longer as the extreme form of social exploitation because the absolute power of the fascists was not influenced by "calculations of usefulness and efficiency", but by the "law of terror". 83 The modernization theory crops up here again, this time under the changed label of a pessimistic critique of civilization. The fundamental agreement between the "positive" and "negative" variants of this model can be seen in the fact that those involved whether as individuals, groups or classes in society - are eliminated along with any kind of historicity. ${ }^{84}$ Instead of history one is offered

73 See Zygmunt Bauman, "Das Jahrhundert der Lager", Neue Gesellschaft - Frankfurter Hefte, 41 (1994), no. 1, pp. 28-37.

7 Zygmunt Bauman, "Living with Alternatives", in idem, Intimations of Postmodernity (London, 1992).

* See Wolfgang Kraushaar, "Sich aufs Eis wagen. Pladoyer für eine Auseinandersetzung mit der Totalitarismustheorie", Mittelweg 36, no. 2 (1993), pp. 6-29; idem, "Antifaschismus und Totalitarismus. Die auf dem linken Auge blinde Linke", Die Zeit, 11 March 1994, p. 70.

${ }^{2}$ See A. S. [Alfons Soellner], " 'Totalitarismus und Modernisierungskritik'. Ankundigung einer theoriegeschichtlichen Konferenz am 8. und 9. Juli 1994", in Hamburger Institut für Sozialforschung (ed.), Bulletin 1995, no. 10, Oct.-Nov. 1993, pp. 66-68; "Projekt 1995: Zivilisation und Barbarei. Zwischenbilanz zu einer Gewaltsgeschichte des 20. Jahrhunderts", ibid., no. 7, April-May 1993, pp. 43-61.

* See the latest example: Wolfgang Sofsky, Die Ordnung des Terrors: Das Konzentrationslager (Frankfurt, 1993).

"Ibid., p. 194. See also, Wolfgang Sofsky, "Formen absoluter Gewalt", Mittelweg 36, no. 5 (1993), pp. 36-46.

"See contrasting opinions to "negative" modernization theories: Götz Aly and Susanne Heim, Vordenker der Vernichtung. Auschwitz und die deutschen Pldne fur eine neue europdische Ordnung (Hamburg, 1991); Wolfgang Schneider (ed.), Vernichtungspolitik. Eine Debatte uber den Zusammenhang von Sozialpolitik und Genozid im nationalsozialistischen Deutschland (Hamburg, 1991). 
teleologically formulated, abstractly defined "logical" developments running in tandem towards the "Moderne". This positions the era of German fascism in a discourse equally far removed from past and present and devoted to the deterministic continuum of "progress".

\section{PARADIGMA CHANGES EVERYWHERE: IS CRITICAL SOCIAL HISTORY OVER?}

In recent years a broadly-based revisionist current has gained entry into all fields of historical research. Sometimes that provokes conflict, as the lengthy controversy surrounding Gottfried Plumpe's attempt to rehabilitate the I.G. Farben concern demonstrates. ${ }^{85}$ The Bochum historian Hans Mommsen and his students have also protested against the interpretation of the Nazi dictatorship based on unquestioned modernization theses. When Mommsen speaks of the Nazi dictatorship as "a feigned modernization", ${ }^{86}$ his remark seems at first glance to represent a hasty concession to the methodological absurdities of historiographical fashion. Mommsen, however, has made it clear that for him the aporia and conclusions of the modernization concept begin to be unacceptable where they are linked to an affirmative historicization postulate. ${ }^{87} \mathrm{We}$ are indebted to Manfred Grieger, a student of Mommsen's, for the first authoritative debate with Zitelmann's allies among the social historians in Bielefeld. ${ }^{83}$ I would also like to refer - in a positive sense - to a critical methodological refiection of Christof Dipper. In the review of an anthology issued by the German "young revisionists", Dipper demonstrated how they reversed cause and effect in their transference of modernization theories into examinations of the Nazi dictatorship: ${ }^{89}$ what looks like purposeful "modernization" was, in historical reality, specific crisis-intervention against the consequences of the transition, generations before, into the capitalist "Moderne".

This notwithstanding, dissenting voices from the ranks of established historians against the revisionist tendencies mentioned above have been

ss Gottfried Plumpe, Die I.G. Farbenindustrie AG. Wirtschaft, Technik, Politik 1904-1945 (Berlin, 1990); Peter Hayes, "Zur umstrittenen Geschichte der I.G. Farbenindustrie AG", Geschichte und Gesellschaft, 18 (1992), pp. 405-417; Thomas Sandkuhler and Hans-Walter Schmuhl, "Noch einmal: Die I.G. Farben und Auschwitz", ibid., 19 (1993), pp. 259-267. ${ }^{86}$ Hans Mommsen, "Nationalsozialismus als vorget从uschte Modernisierung", in idem, Der Notionalsozialismus und die deutsche Gesellschaft (Reinbek bei Hamburg, 1991), pp. 405427.

87 On the occasion of his obituary for Martin Broszat: Hans Mommsen, "Die Gegenwart als Geschichte. Zeitgeschichte als 'kritische Aufklärungsarbeit'. Zur Erinnerung an Martin Broszat (1926-1989)", Geschichte und Gesellschaft, 17 (1991), pp. 141-147.

* Manfred Grieger, "Die Zitelmänner oder Vom Verschwinden der nationalsozialistischen Verbrechen", Zeitschrift marxistische Erneuerung, 4 (1993), no. 15, pp. 254-264.

"Christof Dipper, "Modernisierung des Nationalsozialismus", Neue Politische Literatur, H.3 (1991), pp. $450-456$. 
few and far between. This statement of fact stands in sharp contrast to the following: in the 1970 s and 1980 s an extremely productive, differentiated and critical historiography of the Nazi regime was established and did not allow itself to be diverted by the deficits and compulsion to justify oneself engendered by the "methods debate" initiated by Kocka, Wehler and Broszat. That this happened at all is due in no small part to Tim Mason, the English historian who committed suicide in Rome two years ago. Other innovatory impulses came from modern history scholars in West Berlin and Bochum. Mason's annotated volume of documents, issued in 1975 on the "Working-class and 'National Community" ", explicitly set out to detect class conflicts hidden behind the symbols of "national community"..$^{00}$ Confrontations between workers and capital had not stopped after the German labour movement and the status quo it supported had been destroyed. Mason, holding that class conflict manifested itself in other ways, expressedly indicated that this terrain was now where the usual social, economical and political processes took place. In doing so, he was conscious of the fact that his perspective repeated a view of radicalized class struggle as seen from above. Precisely because of this angle Mason was able to show how fully novel examples of interaction between the civil service, entrepreneurs and workers originated - the "national community" myth was stripped of its mantle. Mason found enough material to document working-class nonconformity towards the regime in the entire pre-war period: 1935-1936, the old open forms of struggle; 1937-1938, in the debate about uncontrollable staff fluctuation. The latter provoked a momentous struggle for power between state functionaries dealing with labour and social policy matters respectively. These contradictions at the top strengthened in turn the willingness to risk a war, thus instrumentalizing old social-imperialistic goals. The self-producing actionism against tyrannical rule is turned upside-down in Mason's account, i.e. it appears as the product of conflicts which have their origins essentially on the factory floor. In the following years Mason formulated more comparative questions and directed his attention directly to the social and subjective behavioural structures of the working class. From the workers' perspective Mason tried to resolve the question to what extent informal "mass resistance" ("Arbeiteropposition") or a "consensus" attitude "purchased" by progressive social measures can be discerned."

90 Timothy W. Mason, Arbeiterklasse und Volksgemeinschaft. Dokumente und Materialien zur deutschen Arbeiterpolitik 1936-1939 (Opladen, 1975).

${ }_{91}$ Timothy W. Mason, "Arbeiteropposition im nationalsozialistischen Deutschland", in Detlev Peukert and Jurgen Reulecke (eds), Die Reihen fast geschlossen (Wuppertal, 1981), pp. 293ff.; idem, "Die Bandigung der Arbeiterklasse im nationalsozialistischen Deutschland", in Carola Sachse et al., Angst, Belohnung, Zucht und Ordnung. Herrschafismechanismen im Nationalsozialismus (Opladen, 1982), pp. 11ff. 
Mason followed this line doggedly and avoided committing himself definitely to any one interpretation.

Mason's initiative was fraught with consequences, even though it was gradually watered down in the course of the many studies it provoked. Up to the beginning of the present decade extensive empirical investigations were published on the relationship between performance, wages and industrial relations. ${ }^{92}$ Cross-section analysis on the quantitative restructuring and segmentation of the working-class were also presented ${ }^{93}$ and strike movements in the years 1935-1937 examined. ${ }^{24}$ The interrelation between industrial female work, work in the home and social policy at the workplace have also been analysed.95 In a word, valuable studies marked the beginnings of a re-evaluation of the entire labour and social policy of the Nazi dictatorship. ${ }^{66}$ Mason's influence could also be traced back to many monographies on daily life under the swastika. However, the foundations laid by Mason soon proved to have cracks. There were defects in his approach: he neglected the work-performance/wage ratio, abstained from referring to the (subjective) class reaction to the (objective) structural changes in the proletariat, and, finally, did not take politically organized resistance into account. It is especially unfortunate that Mason's methodological class-analysis postulate, despite some conceptual parallels offered by social scientists from West Berlin ${ }^{97}$ and lecturers in modern history at Bochum, ${ }^{98}$ did not lead to a new "school". Mason, who lived in Italy from the early 1980 s, clashed there with propagandists who wished to rehabilitate fascism by dressing it up as a

92 Reinhardt Hanf, "Möglichkeiten und Grenzen betrieblicher Lohn- und Gehaltspolitik 1933 bis 1939" (Ph.D. thesis, Regensburg, 1976); Sachse et al., Angst, Belohnung, Zucht und Ordnung; Tilla Siegel, Leistung und Lohn in der nationalsozialistischen "Ordnung der Arbeit" (Opladen, 1989).

93 Radiger Hachtmann, Industriearbeit im "Dritten Reich". Untersuchungen zu den Lohnund Arbeitsbedingungen in Deutschland 1933-1945 (Göttingen, 1989).

* Gunther Morsch, "Streik im 'Dritten Reich'", Vierteljahrshefte fur Zeitgeschichte, 36 (1988), pp. 649ff.; " "Arbeitsniederlegungen in Betrieben'. Ein Bericht des DAFGeheimdienstes aber eine Streikbewegung im Jahre 1936, eingeleitet von Doris Kachulle", 1999, 6 (1991), no. 4, pp. 85-109.

9s Annemarie Tröger, "Die Planung des Rationalisierungsproletariats. Zur Entwicklung der geschlechtsspezifischen Arbeitsteilung und des weiblichen Arbeitsmarktes im Nationalsozialismus", in Annette Kuhn and Jöm Rusen (eds), Frauen in der Geschichte II (Dusseldorf, 1982), pp. 245-298; Carola Sachse, Siemens, der Nationalsozialismus und die moderne Familie. Eine Untersuchung zur sozialen Rationalisierung in Deutschland im 20. Jahrhundert (Hamburg, 1990).

\% Despite thematical limitations, basic research questions are examined by: Martin $\mathbf{H}$. Geyer, Die Reichsknappschaft. Versichenungsreform und Sozialpolitik im Bergbau 190019.45 (Munich, 1987); Matthias Frese, Betriebspolitik im "Dritten Reich". Deutsche Arbeitsfront, Unternehmer und Staatsbarokratie in der westdeutschen Großindustrie 19331939 (Paderborn, 1991).

" See Sachse et al., Angst, Belohnung, Zucht und Ordnung.

* Hans Mommsen and Susanne Willems (eds), Herrschaftsalltag im Dritten Reich. Studien und Texte (Dusseldorf, 1988). 
form of "modernization".99 This conflict remained unknown in Germany and did not provoke any intellectual impulses for German historiography. Unless I am very much mistaken, there is an imminent danger that the critical social history writings on the Nazi regime will be stifled by models of a "modernization" conception placed in the context of nation-state continuity. This is the result of the dilemma, only now apparent in its far-reaching consequences: the very productive empirical research of the 1980 s did not produce any long-term useful epistemological efforts nor did it offer combative replies to the neo-positive conceitedness of dominant historiographical currents.

\section{CONCLUSION}

The historical revisionism of the New Right has its roots in the epistemological deficits and affirmation efforts on the part of the modern history establishment in West Germany and superimposes itself more and more on the structural-analysis approach in social history scholarship. The undoubtedly pioneering successes of the group around Zitelmann and Prinz would not have been possible without the guidelines laid down by Broszat, e.g. "modernization" theory and his efforts at affirmative writing. The core thesis of the revisionists, namely that German fascism represents an indispensable and legitimate component of the teleological continuum to the "Moderne", opened the sluice gates. Starting from this axiom and proceeding step by step, the "socially progressive" institutions of the Nazi tyranny were rehabilitated and the propaganda fantasyworld of the "national community" portrayed as a social reality. Furthermore, the mass executions were excluded from discussion by presenting them as inevitable or marginable facts of a secular modernization trend, or alternatively by reproducing them as part of "negative modernization". The revisionists succeeded with such methods in bundling the eclectic deficits and affirmation efforts of dominant historiography and presenting the mixture as a new "historical perspective". Thus, in the end, it was possible to dismiss the efforts of reactionary historians to legitimize the Nazi dictatorship with global-defensive arguments as a "slip up" in the "world's civil war". The revisionist offensive then went into top gear. Due to their efforts, German fascism is now interpreted increasingly as the positive completion of Prussian-German national power politics, which deserve rehabilitation in its "moderate" variant. The "national community", now rehabilitated socially, politically and historically, is associated with the "powerful State" concept and employed at home and abroad as legitimation for a new departure in politics. The revisionist historians see themselves as pioneers in the struggle now beginning between mentalities, a struggle in which the New

"Mason, "Il fascismo "Made in Italy" "; idem, "Moderno, modernita, modernizzazione". 
Right hopes to eliminate the last remnants of the - in their eyes, obscene - democraticization process in the West Germany of the 1960s and early 1970s. The "prescribed" antifascism of the GDR, whose deficits in social history are not being overlooked in these pages, has been eliminated in the meantime.

The "Historikerstreit" evoked fierce controversies, but today no resistance stirs against historical revisionism, which acts as a hinge between conservative elites and the New Right. Apart from general trends in Europe, I see the main reason for this silence in the fact that leading West German historians refused to support their reform-oriented colleagues in the GDR in the years 1989/1990 and took part instead in the demolition of East German historical science. Any historian who, for career reasons, participated in the colonization of third-level education in the former GDR, had to buckle under the yoke of the new "national consciousness" sooner or later. More important than the integrity of research intentions are ideological justifications from the arsenal of "national" values. The conclusiveness of the latter does not evince the slightest interest and, in any case, is detrimental to theoretical discourse. When such "adaptable" historians then even jeer at the "prescribed antifascism" of the GDR, they have to expect the counter-question: whether, in the face of their own theory that the working class was smoothly integrated into the Nazi system, "another" form of antifascism was possible, or perhaps better, none at all? Complicity can also arise on the basis of concrete political activity, for our purposes complicity with those who would consider the "delayed" antifascism of the 1968 generation as the last barrier to attempts at revising history.

These developments are alarming. How can we counteract them? By raising this question at the conclusion of my comments, I proceed implicitly from the opinion that historical revisionism could possibly become the dominant tendency in historical scholarship, even though this has not occurred as yet. We have no reason to panic if we consider the actual political situation and the likelihood that socio-economic factors will lead to the demolition of the "Prussian-German strong State" fixation in the years to come. A pre-condition is, however, that we engage ourselves fully in the political and historical debate. Starting from present-day tendencies, we should be prepared to examine previous approaches at formulating a critical historico-structural analysis of the Nazi period. In one of his last papers Tim Mason called for new exertions in theorizing on fascism by including all previous research findings. ${ }^{100}$

I think the time is more than ripe for such an initiative in Germany. Writers on the social history of Hitler's dictatorship should think back to their class-analysis premisses. Moreover, they should refer their mani(eds), Reevaluating the Third Reich (New York and London, 1993), pp. 253-262. 
fold and disparate fields of study to one another: labour and social history, analysis of the Holocaust, etc. Leading themes and questions that complement one another deserve full discussion in the permanent debate with revisionistic historical models. For example, the suicide of the German labour movement for fear of being destroyed, the structural breaks and discontinuities of labour and social legislation, the combined deregulation and Keynesian policies exercised by industry and power politics, the mental influence of "national community" mass-propaganda on actual class relationships, the socio-economic background to "liquidation by (forced) labour", the transformation of the European labour movement in the interplay between occupiers and collaborators. All that assumes, however, that we take the responsibility of historical research for the present and the future seriously. It is better to meet this challenge than to hope for an easy academic life - an unlikely prospect in any case.

Translated by Barry McLoughlin 